\title{
ANALISIS SOAL HIGHER ORDER THINKING SKILL (HOTS) BAHASA INDONESIA DALAM UJIAN SEKOLAH SMP NEGERI 4 DUMAI
}

\author{
Rifka Rifana ${ }^{1}$, Dudung Burhanudin ${ }^{2}$, Elvrin Septiyanti ${ }^{3}$ \\ Mahasiswa Universitas Riau ${ }^{1}$, Dosen Universitas Riau ${ }^{2}$, Dosen Universitas Riau ${ }^{3}$ \\ Kampus Bina Widya, Simpang Baru, Pekanbaru \\ Sur-el: rifkarifana2@gmail.com ${ }^{1}$, dudungburhanuddin@gmail.com², \\ elvrin.septyanti@lecturer.unri.ac.id ${ }^{3}$
}

Article info

Article history:

Received:27-05-2021

Revised :05-06-2021

Accepted:22-08-2021

Keywords:

Analysis of HOTS

Questions, Taxonomy

Bloom, Indonesians

Subject Test

Questions

Kata Kunci:

Analisis soal HOTS,

Taksonomi Bloom,

Soal Tes Bahasa

Indonesia

\begin{abstract}
A B S T R A C T
This research is a teaching field research on the analysis of the Higher Order Thinking Skill (HOTS) type of exam questions for Nineth Grade Students of SMP Negeri 4 Dumai. The problem examined in this study is how many levels of HOTS (Higher Order Thinking Skill) questions are contained in the school exam questions. This type of research is quantitative. The source of the data in this study came from the document of the school exam questions for Indonesian subjects for nineth grade students of SMP Negeri 4 Dumai for the 2019/2020 academic year, which consisted of 40 multiple choice questions. The results of this study indicate that $32.5 \%$ are classified as HOTS (Higher Order Thinking Skill) questions and 67.5\% are classified as MOTS (Middle Order Thinking Skills).
\end{abstract}

Penelitian ini merupakan penelitian bidang pengajaran tentang analisis soal tipe Higher Order Thinking Skill (HOTS) pada soal Ujian Sekolah Siswa Kelas IX SMP Negeri 4 Dumai. Permasalahan yang diteliti dalam penelitian ini adalah berapa tingkat soal HOTS (Higher Order Thinking Skill) yang terdapat pada soal Ujian Sekolah tersebut. Jenis penelitian ini adalah kuantitatif. Sumber data dalam penelitian ini berasal dari dokumen butir soal Ujian Sekolah mata pelajaran Bahasa Indonesia untuk siswa kelas IX SMP Negeri 4 Dumai Tahun Ajaran 2019/2020, yang terdiri dari 40 butir soal pilihan ganda. Hasil penelitian ini menunjukkan bahwa sebesar $32,5 \%$ tergolong soal HOTS (Higher Order Thinking Skill) dan 67,5\% tergolong MOTS (Middle Order Thinking Skill). 


\section{JURNAL ILMIAH \\ BINA EDUKASI \\ ISSN 1979-8598 E-ISSN: 2655-8378 \\ http://journal.binadarma.ac.id/index.php/jurnalbinaedukasi \\ Vol. 14, No. 2, Desember 2021, 121 - 129}

\section{PENDAHULUAN}

Dengan adanya perangkat mata pelajaran yang akan diajarkan oleh guru, diharapkan siswa dapat mengasah keterampilan berpikirnya. Dengan mengasah keterampilan berpikir yang dimiliki siswa mulai dari tingkatan rendah, sedang, hingga yang tinggi merupakan usaha untuk meningkatkan kualitas pembelajaran dan kualitas lulusan di setiap sekolah yang dikembangkan oleh Kementrian Pendidikan dan Kebudayaan melalui Direktorat Jenderal Guru dan Tenaga Kependidikan (Dirjen GTK). Peningkatan kualitas pembelajaran dan kualitas lulusan tersebut dapat ditempuh salah satunya dengan cara meningkatkan kualitas berpikir siswa. Keterampilan berpikir tersebut terbagi menjadi tiga, yaitu LOTS (Lower Order Thinking Skill) yang berkategori tingkat berpikir yang rendah, MOTS (Middle Order Thinking Skill) yang berkategori tingkat berpikir yang sedang, dan HOTS (Higher Order Thinking Skill) yang berkategori tingkat berpikir yang tinggi. Menurut Gunawan (2012) kemampuan berpikir tingkat tinggi adalah proses berpikir yang mengharuskan peserta didik untuk memanipulasi informasi dan ide-ide yang didapatkannya dalam cara tertentu sehingga dapat memberikan mereka pengertian dan implikasi baru.

Setiap keterampilan berpikir tersebut memiliki manfaat dan dampak yang berbeda-beda pada setiap siswa di sekolah. Misalnya pada pembelajaran yang menggunakan keterampilan berpikir tingkat rendah atau LOTS (Lower Order Thinking Skill) menghasilkan siswa yang tidak memiliki keterampilan berpikir tingkat tinggi. Ketidakmampuan siswa dalam mengembangkan keterampilan berpikir tingkat tingkat tinggi atau berpikir kritis yang mereka miliki akan menyebabkan siswa tersebut tidak mampu dalam mengembangkan ide-ide baru yang dibutuhkan untuk pengembangan karya atau usaha, sehingga ketika mendapati sebuah tantangan di luar dunia pendidikan, siswa tidak terbiasa untuk melatih pikirannya untuk selalu berpikir kreatif dan tidak merasa aman ketika harus mengikuti perubahan signifikan di dalam dunia. Downing (1997) dalam Abdullah, Ridwan (2019) mendefinisikan kreativitas sebagai proses untuk menghasilkan sesuatu yang baru dari elemen yang telah ada dan dengan menyusun kembali elemen tersebut, sedangkan bepikir kritis menurut Halpern (dalam Abdullah, Ridwan: 2019: 14), berpikir kritis berkaitan dengan penggunaan keterampilan kognitif atau strategi yang meningkatkan kemungkinan untuk memperoleh dampak yang diinginkan.

HOTS (Higher Order Thinking Skill diperlukan untuk melatih keterampilan berpikir siswa sehingga siswa terbiasa dan mampu ketika mendapati soal atau pelajaran yang berbasis HOTS (Higher Order Thinking Skill). Menurut Thomas \& Thorne (dalam Nugroho, Arifin 


\section{JURNAL ILMIAH \\ BINA EDUKASI \\ ISSN 1979-8598 E-ISSN: 2655-8378 \\ http://journal.binadarma.ac.id/index.php/jurnalbinaedukasi \\ Vol. 14, No. 2, Desember 2021, 121 - 129}

(2018) HOTS (Higher Order Thinking Skill) merupakan cara berpikir yang lebih tinggi daripada menghafalkan fakta, mengemukakan fakta, atau menerapkan peraturan, rumus, dan prosedur. Selain itu juga, HOTS (Higher Order Thinking Skill) berguna untuk memperbaiki kinerja siswa dalam proses pembelajarannya. Melatih berpikir tinggi artinya siswa diarahkan untuk berpikir kritis terhadap suatu masalah. Siswa diminta untuk melakukan pemecahan masalah terlebih dahulu sebelum menjawab soal. Karena soal yang berbasis HOTS (Higher Order Thinking Skill) tidak serta merta berupa mengingat. Namun, sudah pada tahap menganalisis, mengevaluasi, dan mencipta. Melatih berpikir tinggi juga berkaitan dengan tercapainya tujuan pendidikan, yaitu memampukan peserta didik dengan karakter beriman dan bertakwa kepada Tuhan, berakhlak mulia, sehat, berilmu, cakap, mandiri, kreatif, serta menjadi warga Negara yang demokratis dan bertanggungjawab untuk menghadapi kehidupannya setelah menamatkan sekolahnya. Anderson dan Krathwol melakukan revisi pada Taksonomi yang selama ini telah digunakan yaitu taksonomi Bloom, bentuk revisian tersebut menghasilkan dimensi proses kognitif (Anderson, 2001).

Penelitian tentang analisis soal HOTS juga pernah dilakukan sebelumnya oleh Imeda (2018) tentang Analisis Soal dalam Buku Mandiri Bahasa Indonesia Kelas VII Berdasarkan Perspektif Higher Order Thinking Skills (HOTS) di SMP Negeri 18 Medan" yang menunjukkan bahwa $47 \%$ soal tergolong LOTS, $41 \%$ soal tergolong MOTS, dan $12 \%$ soal tergolong HOTS. Pada 2019, Wulandari, dkk. Meneliti tentang “Analisis Butir Soal HOTS pada Soal Ujian Sekolah Kelas XII Mata Pelajaran Bahasa Indonesia di SMK An-Nahl" yang menunjukkan bahwa $22,2 \%$ soal LOTS yang terdiri dari $0 \%$ level C1; 8,9\% level C2; dan 13,3\% level C3; serta sebesar 77,8\% soal HOTS yang terdiri dari 55,7\% level C4, 6,7\% level C5, dan 4,4\%level C6. Selanjutnya, Chandra dan Heryadi (2020) meneliti tentang “Kemampuan Guru Bahasa Indonesia dalam Membuat Soal Tes Berbasis HOTS (Higher Order Thinking Skills) di SMP Sekecamatan KarangNunggal" yang menunjukkan bahwa kemampuan guru Bahasa Indonesia dalam mengembangkan soal tes Bahasa Indonesia berbasis HOTS masih rendah, serta soal yang disusun belum menggunakan stimulus yang menarik, kontekstual dan belum mengukur kemampuan kognitif level analisis, evaluasi, maupun mencipta.

Oleh karena itu, peneliti sangat tertarik dengan peganalisisan soal Ujian Sekolah mata pelajaran Bahasa Indonesia untuk siswa kelas IX SMP Negeri 4 Dumai tersebut untuk dapat mengetahui seberapa banyak soal yang berkategori HOTS (Higher Order Thinking Skill) dan yang tidak berkategori HOTS atau berada pada kategori sedang MOTS (Middle Order Thinking Skill), dan yang berkategori rendah atau LOTS (Lower Order Thinking Skil). 


\section{METODOLOGI PENELITIAN}

Jenis penelitian ini adalah penelitian kuantitatif atau dapat diartikan sebagai penelitian yang objeknya secara khusus dapat diteliti secara statistik. Penelitian kuantitatif menurut Sugiyono (2019), adalah metode penelitian yang berkiblat pada filsafat positivisme yang digunakan untuk meneliti penelitian pada bagian populasi dan sampel tertentu, pengumpulan data penelitian yang menggunakan instrumen penelitian, analisis data berupa kuantitatif atau statistik untuk dapat menguji hipotesis yang telah ditetapkan.

Data dalam penelitian ini adalah butir soal Ujian Sekolah mata pelajaran Bahasa Indonesia untuk siswa kelas IX SMP Negeri 4. Sumber data dalam penelitian ini berasal dari dokumen butir soal Ujian Sekolah mata pelajaran Bahasa Indonesia untuk siswa kelas IX SMP Negeri 4 Dumai Tahun Ajaran 2019/2020, yang terdiri dari 40 butir soal pilihan ganda yang didapatkan dari responden yaitu guru Bahasa Indonesia, Ibu Sarifah, S.Pd yang membuat soal Ujian Sekolah mata pelajaran Bahasa Indonesia untuk siswa kelas IX SMP Negeri 4 Dumai, dan peserta didik yang mengikuti tes ini.

Teknik pengumpulan data dalam penelitian ini adalah dengan menggunakan studi dokumentasi, yaitu dokumen tersebut berupa lembar soal Ujian Sekolah. Menurut Sugiyono (2019) menyatakan bahwa studi dokumentasi adalah dokumen yang berupa catatan peristiwa yang sudah berlalu.

Teknik analisis data dalam penelitian ini adalah (1) Menganalisis butir soal Ujian Sekolah mata pelajaran Bahasa Indonesia untuk siswa kelas IX SMP Negeri 4 Dumai berdasarkan level berpikir C1-C6, (2) Mengklasifikasikan banyaknya butir soal Ujian Sekolah mata pelajaran Bahasa Indonesia untuk siswa kelas IX SMP Negeri 4 Dumai yang tergolong dalam soal yang berategori HOTS (Higher Order Thinking Skill), MOTS (Middle Order Thinking Skill), atau LOTS (Lower Order Thinking Skill), (3) Memersenkan tiap tingkatan soal yang berkategori HOTS (Higher Order Thinking Skill), MOTS (Middle Order Thinking Skill), atau LOTS (Lower Order Thinking Skill) dengan menggunakan rumus, (4) Menyimpulkan hasil analisis butir soal soal Ujian Sekolah mata pelajaran Bahasa Indonesia untuk siswa kelas IX SMP Negeri 4 Dumai. Untuk memersenkan hasil analisis soal yang diteliti digunakan rumus Ali, Muhammad (2013), sebagai berikut. 


$$
K=\frac{K i}{\text { Total soal }} \times 100
$$

Keterangan:

$\mathrm{K}$

: Persentase dari masing-masing kategori soal

$\mathrm{Ki}$ : Banyaknya butir soal hasil analisis dari Kata Kerja Operasinal C1-C6

Total soal : banyak soal yang akan dianalisis

Hasil persen dari analisis soal tersebut dapat diklasifikasikan berdasarkan tabel kriteria kesesuaian berikut:

Tabel 1. Kriteria Kesesuaian

\begin{tabular}{cc}
\hline Skala & Keterangan \\
\hline $0 \%-20 \%$ & Sebagian kecil \\
$21 \%-40 \%$ & Kurang dari setengah \\
$41 \%-60 \%$ & Setengah \\
$61 \%-80 \%$ & Sebagian besar \\
$81 \%-100 \%$ & Hampir semua \\
\hline \multicolumn{2}{c}{ Sumber: Arikunto (2001) }
\end{tabular}

\section{HASIL DAN PEMBAHASAN}

Berdasarkan hasil analisis yang telah dilakukan peneliti terhadap dokumen soal Ujian Sekolah mata pelajaran Bahasa Indonesia untuk siswa kelas IX SMP Negeri 4 Dumai Tahun Ajaran 2019/2020, diketahui bahwa tidak terdapat soal dengan kategori rendah atau LOTS (Lower Order Thinking Skill), terdapat 27 soal berkategori MOTS (Middle Order Thinking Skill), terdapat 13 soal berkategori HOTS (Higher Order Thinking Skill). Berikut tabel penganalisisan soal Ujian Sekolah tersebut :

Tabel 2. Hasil Analisis Soal Ujian Sekolah

\begin{tabular}{cccc}
\hline NOMOR SOAL & JENIS SOAL & RANAH KOGNITIF & $\begin{array}{c}\text { KATEGORI } \\
\text { SOAL }\end{array}$ \\
\hline Soal nomor 1 & Pilihan Ganda & C2 Memahami & MOTS \\
Soal nomor 2 & Pilihan Ganda & C4 Menganalisis & HOTS \\
Soal nomor 3 & Pilihan Ganda & C5 Mengevaluasi & HOTS \\
\hline
\end{tabular}




\begin{tabular}{|c|c|c|c|}
\hline Soal nomor 4 & Pilihan Ganda & C4 Menganalisis & HOTS \\
\hline Soal nomor 5 & Pilihan Ganda & C4 Menganalisis & HOTS \\
\hline Soal nomor 6 & Pilihan Ganda & C4 Menganalisis & HOTS \\
\hline Soal nomor 7 & Pilihan Ganda & C2 Memahami & MOTS \\
\hline Soal nomor 8 & Pilihan Ganda & C2 Memahami & MOTS \\
\hline Soal nomor 9 & Pilihan Ganda & C4 Menganalisis & HOTS \\
\hline Soal nomor 10 & Pilihan Ganda & C2 Memahami & MOTS \\
\hline Soal nomor 11 & Pilihan Ganda & C3 Menerapkan & MOTS \\
\hline Soal nomor 12 & Pilihan Ganda & C4 Menganalisis & HOTS \\
\hline Soal nomor 13 & Pilihan Ganda & C3 Menerapkan & MOTS \\
\hline Soal nomor 14 & Pilihan Ganda & C2 Memahami & MOTS \\
\hline Soal nomor 15 & Pilihan Ganda & C3 Menerapkan & MOTS \\
\hline Soal nomor 16 & Pilihan Ganda & C3 Menerapkan & MOTS \\
\hline Soal nomor 17 & Pilihan Ganda & C3 Menerapkan & MOTS \\
\hline Soal nomor 18 & Pilihan Ganda & C2 Memahami & MOTS \\
\hline Soal nomor 19 & Pilihan Ganda & C2 Memahami & MOTS \\
\hline Soal nomor 20 & Pilihan Ganda & C2 Memahami & MOTS \\
\hline Soal nomor 21 & Pilihan Ganda & C2 Memahami & MOTS \\
\hline Soal nomor 22 & Pilihan Ganda & C3 Menerapkan & MOTS \\
\hline Soal nomor 23 & Pilihan Ganda & C3 Menerapkan & MOTS \\
\hline Soal nomor 24 & Pilihan Ganda & C3 Menerapkan & MOTS \\
\hline Soal nomor 25 & Pilihan Ganda & C3 Menerapkan & MOTS \\
\hline Soal nomor 26 & Pilihan Ganda & C3 Menerapkan & MOTS \\
\hline Soal nomor 27 & Pilihan Ganda & C3 Menerapkan & MOTS \\
\hline Soal nomor 28 & Pilihan Ganda & C3 Menerapkan & MOTS \\
\hline Soal nomor 29 & Pilihan Ganda & C3 Menerapkan & MOTS \\
\hline Soal nomor 30 & Pilihan Ganda & C3 Menerapkan & MOTS \\
\hline Soal nomor 31 & Pilihan Ganda & C4 Menganalisis & HOTS \\
\hline Soal nomor 32 & Pilihan Ganda & C4 Menganalisis & HOTS \\
\hline Soal nomor 33 & Pilihan Ganda & C4 Menganalisis & HOTS \\
\hline Soal nomor 34 & Pilihan Ganda & C3 Menerapkan & MOTS \\
\hline Soal nomor 35 & Pilihan Ganda & C3 Menerapkan & MOTS \\
\hline Soal nomor 36 & Pilihan Ganda & C3 Menerapkan & MOTS \\
\hline Soal nomor 37 & Pilihan Ganda & C4 Menganalisis & HOTS \\
\hline Soal nomor 38 & Pilihan Ganda & C4 Menganalisis & HOTS \\
\hline Soal nomor 39 & Pilihan Ganda & C4 Menganalisis & HOTS \\
\hline Soal nomor 40 & Pilihan Ganda & C3 Menerapkan & MOTS \\
\hline
\end{tabular}

Butir soal Ujian Sekolah mata pelajaran Bahasa Indonesia untuk siswa kelas IX SMP Negeri 4 Dumai yang berada pada kategori sedang atau MOTS (Middle Order Thinking Skill) pada Taksonomi Bloom berada pada level 2 dan 3 yaitu memahami dan menerapkan. Pada level 2 soal-soal tersebut membutuhkan pemahaman siswa terhadap teks bacaan yang telah tersedia 


\section{JURNAL ILMIAH}

BINA EDUKASI

ISSN 1979-8598 E-ISSN: 2655-8378

http://journal.binadarma.ac.id/index.php/jurnalbinaedukasi

Vol. 14, No. 2, Desember 2021, 121 - 129

pada butir soal, misalnya (1) mengartikan atau menanyakan makna akan suatu kata atau kalimat, (2) membandingkan dua objek, ataupun (3) merangkum dari cerita pada teks bacaan butir soal. Pada level 3 soal-soal tersebut membutuhkan penentuan kata atau kalimat atau objek yang tepat terhadap teks-teks butir soal, misalnya (1) menentukan watak tokoh / latar / nilai moral suatu teks bacaan butir soal, (2) mengurutkan suatu prosedur, ataupun (3) mengaitkan pilihan jawaban dengan teks bacaan butir soal.

Butir soal yang berada pada kategori tinggi atau HOTS (Higher Order Thinking Skill) pada Taksonomi Bloom berada pada level 4 dan 5 yaitu menganalisis dan mengevaluasi. Pada level 4 soal-soal tersebut membutuhkan penganalisisan yang tajam dari siswa, misalnya (1) menemukan ide pokok, kalimat utama, maupun pendapat yang mendukung, dan (2) mengoreksi kesalahan penggunaan kata atau kalimat. Pada level 5 soal tersebut membutuhkan evaluasi atau penilaian, misalnya (1) menyimpulkan isi dari teks bacaan butir soal.

Kemudian soal tersebut dihitung persentasenya untuk dapat diketahui krikeria kesesuaiannnya dari hasil perhitungan persentase tersebut. Berikut ini adalah perhitungan mencari persentase hasil analisis HOTS (Higher Order Thinking Skill) butir soal dengan rumus adalah sebagai berikut :

1. LOTS (Lower Oerder Thinking Skill),

$$
K=\frac{0}{40} \times 100 \%=0 \%
$$

2. MOTS (Middle Order Thinking Skill),

$$
K=\frac{27}{40} \times 100 \%=67,5 \%
$$

3. HOTS (Higher Order Thinking Skill),

$$
K=\frac{13}{40} \times 100 \%=32,5 \%
$$

Dari hasil perhitungan menggunakan rumus tersebut dapat diketahui bahwa kriteria dari soal Ujian Sekolah mata pelajaran Bahasa Indonesia untuk siswa kelas IX SMP Negeri 4 Dumai adalah sebagai berikut :

Tabel 3. Ktriteria soal

\begin{tabular}{cccc}
\hline Skala & Kriteria & Hasil & Keterangan \\
\hline $0 \%-20 \%$ & Sebagian kecil & $0 \%$ & LOTS ((Lower Oerder Thinking Skill) \\
$21 \%-40 \%$ & Kurang dari setengah & $32,5 \%$ & HOTS (Higher Order Thinking Skill) \\
$61 \%-80 \%$ & Sebagian besar & $67,5 \%$ & MOTS(Middle Order Thinking Skill) \\
\hline
\end{tabular}




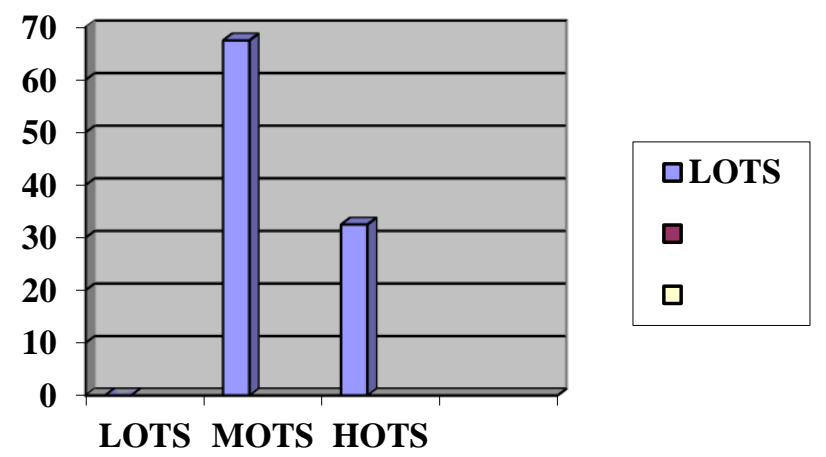

Grafik 1. Hasil Analisis Soal

\section{SIMPULAN}

Berdasarkan penelitian yang telah dilakukan tentang analisis soal tipe HOTS (Higher Order Thinking Skill) mata pelajaran Bahasa Indonesia untuk siswa kelas IX SMP Negeri 4 Dumai dapat disimpulkan bahwa analisis soal berdasarkan taksonomi Bloom yang direvisi oleh Anderson \& Krathwol kurang dari setengah soal tersebut berkategori HOTS (Higher Order Thinking Skill) dan sebagian besar soal tersebut berkategori MOTS (Middle Order Thinking Skill).

\section{DAFTAR PUSTAKA}

Abdullah, Ridwan. (2019). Pembelajaran Berbasis HOTS (Higher Order Thinking Skill. Tangerang: Tsamart Printing.

Ali, Muhammad. (2013). Penelitian Kependidikan Prosedur dan Strategi. Bandung: Angkasa.

Anderson, L.W. (Ed) dan Krathwol, D.R. (Ed)., (2001). A Taxonomy for Learnin, Teaching And Assessing: A Revision Of Bloom's Taxonomy Of Educational Objectives. New York. Longman.

Arikunto, Suharsimi. (2008). Dasar-dasar Evaluasi Pendidikan. Jakarta: Bumi Aksara.

Chandra, Deni dan Dedi Heryadi. (2020). Kemampuan Guru Bahasa Indonesia dalam Membuat Soal Tes Berbasis HOTS (Higher Order Thinking Skills) di SMP Sekecmatan Karangnunggal". Fon: Jurnal Pendidikan Bahasa dan Sastra 16(1), $22-28$.

Gunawan, I dan Palupi. (2012). Taksonomi Bloom Revisi-Revisi Ranah Kognitif. Kerangka Landasan untuk Pemebelajaran dan Penilaian Skripsi. Madiun. FIP IKIP PGRI Madiun. 


\section{JURNAL ILMIAH}

BINA EDUKASI

ISSN 1979-8598 E-ISSN: 2655-8378

http://journal.binadarma.ac.id/index.php/jurnalbinaedukasi

Vol. 14, No. 2, Desember 2021, 121 - 129

Imelda, Putri. (2018). Analisis Soal dalam Buku Mandiri Bahasa Indonesia Kelas VII Berdasarkan Perspektif Higher Order Thinking Skills (HOTS) di SMP Negeri 18 Medan. Skripsi tidak Dipublikasikan. Universitas Negeri Medan: Medan.

Nugroho, Arifin. (2018). HOTS Kemampuan Berpikir Tingkat Tinggi: Konsep, Pembelajaran, Penilaian, \& Soal-Soal. Jakarta: PT Gramedia Widiasarana Indonesia.

Sugiyono. (2019). Metode Penelitian Pendidikan Pendekatan Kuantitatif, Kualitatif, dan R\&D. Bandung: Alfabeta.

Wulandari, Tari, dkk. (2019). Analisis Butir Soal HOTS (Higher Order Thinking Skill) pada Soal Ujian Sekolah Kelas XII Mata Pelajaran Bahasa Indonesia di SMK An-Nahl. Parole: Jurnal Pendidikan Bahasa Indonesia dan Sastra Indonesia, 2 (4), 485—493. 